\title{
Lizard assemblage from a sand dune habitat from southeastern Brazil: a niche overlap analysis
}

\author{
GISELE R. WINCK ${ }^{1}$, FABIO HATANO ${ }^{2}$, DAVOR VRCIBRADIC ${ }^{3}$, \\ MONIQUE VAN SLUYS ${ }^{1}$ and CARLOS F.D. ROCHA ${ }^{1}$ \begin{abstract}
Rua São Francisco Xavier, 524, Pavilhão Haroldo Lisboa, sala 220, Maracanã, 20550-013 Rio de Janeiro, RJ, Brasil ${ }^{2}$ Instituto Socioambiental e dos Recursos Hídricos (ISARH), Universidade Federal Rural da Amazônia, Av. Presidente Tancredo Neves, 2501, Montese, 66077-901 Belém, PA, Brasil ${ }^{3}$ Departamento de Zoologia, Instituto de Biociências, Universidade Federal do Estado do Rio de Janeiro, Av. Pasteur, 458, sala 402, Urca, 22290-240 Rio de Janeiro, RJ, Brasil
\end{abstract} \\ ${ }^{1}$ Departamento de Ecologia, Instituto de Biologia Roberto de Alcântara Gomes, Universidade do Estado do Rio de Janeiro, \\ Manuscript received on May 13, 2015; accepted for publication on July 11, 2015
}

\begin{abstract}
Communities are structured by interactions of historical and ecological factors, which influence the use of different resources in time and space. We acquired data on time of activity, microhabitat use and diet of a lizard assemblage from a sand dune habitat in a coastal area, southeastern Brazil (Restinga de Jurubatiba). We analyzed the data of niche overlap among species in these three axes (temporal, spatial and trophic) using null models. We found a significant overlap within the trophic niche, whereas the overlap for the other axes did not differ from the expected. Based on this result, we discuss the factors acting on the structure of the local lizard community.
\end{abstract}

Key words: null models, communities, sand dune habitat, lizards, Brazil.

\section{INTRODUCTION}

The structuring of communities is modeled by interactions of both historical and ecological factors (e.g., Araújo 1994, Vitt 1995). Ecological factors comprise mainly interactions between sympatric species and their relationships with the local environment, which ultimately may result in the segregation of basic resources used by species (e.g., food, microhabitat and time of activity; Pianka 1973, Schoener 1974, Toft 1985, Araújo 1994). Differences on how sympatric species

Correspondence to: Gisele R. Winck

E-mail: gwinck@gmail.com use available resources may be influenced by the community itself (ecological factors), and/or may reflect a historical divergence (historical factors) (Vitt et al. 1999, Vitt and Pianka 2005). Even the availability of a given resource may vary in time and space, according to consumers and behavioral divergences (Winemiller and Pianka 1990). Also, temporal differences in activity and in microhabitat used influence the resource acquisition (Winemiller and Pianka 1990). A methodology to interpret its structure evaluates the overlap of different niche axes from species in a community, and involves the construction of random null models (pseudocommunities or null models) based on real data 
(Gotelli and Graves 1996). This methodology was proposed during the 1970's (Sale 1974) and since then, has been used in many studies (e.g., Winemiller and Pianka 1990, Gainsbury and Colli 2003).

Most ecological studies on the structure of lizard assemblages have been carried out in deserts and mostly in temperate areas (e.g., Pianka 1986, Winemiller and Pianka 1990, Vitt 1995). Nevertheless, comparative ecological studies on lizard assemblages in tropical cis-Andean South America have increased considerably in number over the last decades, encompassing different habitats such as Amazonian Rainforest (Rand and Humphrey 1968, Magnusson et al. 1985, Duellman 1987, Martins 1991, Vitt and Zani 1996, 1998), Amazonian savanna (Vitt and Carvalho 1995, Mesquita et al. 2006a), Brazilian Cerrado (Vitt 1991, Mesquita et al. 2006b), and dry Caatinga from northeastern Brazil (Vitt 1995, Rocha and Rodrigues 2005). Both qualitative and quantitative studies are scarce for lizard assemblages occurring within the Atlantic Rainforest domain and, with a few exceptions (e.g., Sazima and Haddad 1992, Freire 1996, Carvalho et al. 2007), most information came from the comparative studies of Araújo $(1984,1991)$ on the lizard assemblage of Barra de Maricá, southeastern Brazil. Additionally, some studies have been done on individual lizard species from that assemblage (e.g., Rocha 1998, 2008, Teixeira-Filho et al. 1995, Rocha and Vrcibradic 1996, 1999, Vrcibradic and Rocha 1996), and in other similar sites in southeastern and southern Brazil (e.g., Bergallo and Rocha 1993, 1994, Verrastro and Krause 1994, Vrcibradic and Rocha 1996, Verrastro and Bujes 1998, Teixeira and Giovanelli 1999, Hatano et al. 2001, Siqueira et al. 2013). However, information on interactions among species comprising these communities is still limited.

In this study we present basic ecological data on sympatric lizard species from a coastal area in the Atlantic Rainforest domain (Restinga de Jurubatiba). Our purpose was to assess the interspecific overlap in temporal, spatial and trophic axes, to analyze a possible influence on the structure of the lizard assemblage.

\section{MATERIALS AND METHODS}

\section{STUDY AREA}

We carried out the study in the Parque Nacional da Restinga de Jurubatiba, situated between $22^{\circ}$ and $22^{\circ} 23^{\prime} \mathrm{S}$ and between $41^{\circ} 15^{\prime}$ and $41^{\circ} 45^{\prime} \mathrm{W}$ (Figure 1). The area spans three municipalities (Macaé, Carapebus and Quissamã) in northeastern Rio de Janeiro state. Jurubatiba is part of a continuous sand dunes complex extending through ca. 6,000 $\mathrm{km}^{2}$ of coastal plains (Araújo and Henriques 1984) in Southeastern Brazil. Rainfall is seasonal and varies from 1,100 to $1,300 \mathrm{~mm}$ annually; monthly average ranges from $41 \mathrm{~mm}$ during winter (June to September) to $189 \mathrm{~mm}$ in summer (December to March; Araújo et al. 1998). Monthly average temperature varies from $29.7{ }^{\circ} \mathrm{C}$ in January to 20 ${ }^{\circ} \mathrm{C}$ in July; annual temperature averages $22.6{ }^{\circ} \mathrm{C}$ (Henriques et al. 1986).

Open coastal sand dune habitats are inserted in the Atlantic Rainforest biome domain. Their main features include the change of vegetation zones as the distance from seashore increases (see Araújo and Henriques 1984): i) beach vegetation, comprised mainly by herbaceous halophilous species; ii) shrubby vegetation; iii) arbustivearboreal vegetation; iv) closed vegetation, composed mainly by arboreal trees with liana species; and v) "restinga" forest, characterized by trees of reduced height compared to those in the ombrophilous forest. A comprehensive description of the vegetation in the area can be found in Araújo et al. (1998). The current configuration of sanddune habitats is relatively recent due to marine regressions and transgressions (see Martin et al. 1996, 2003, Cerqueira 2000). In these coastal habitats, lizards are usually in high densities (Rocha and Bergallo 1997). Lizard assemblages in those areas are typically structured by "invasion" (see 


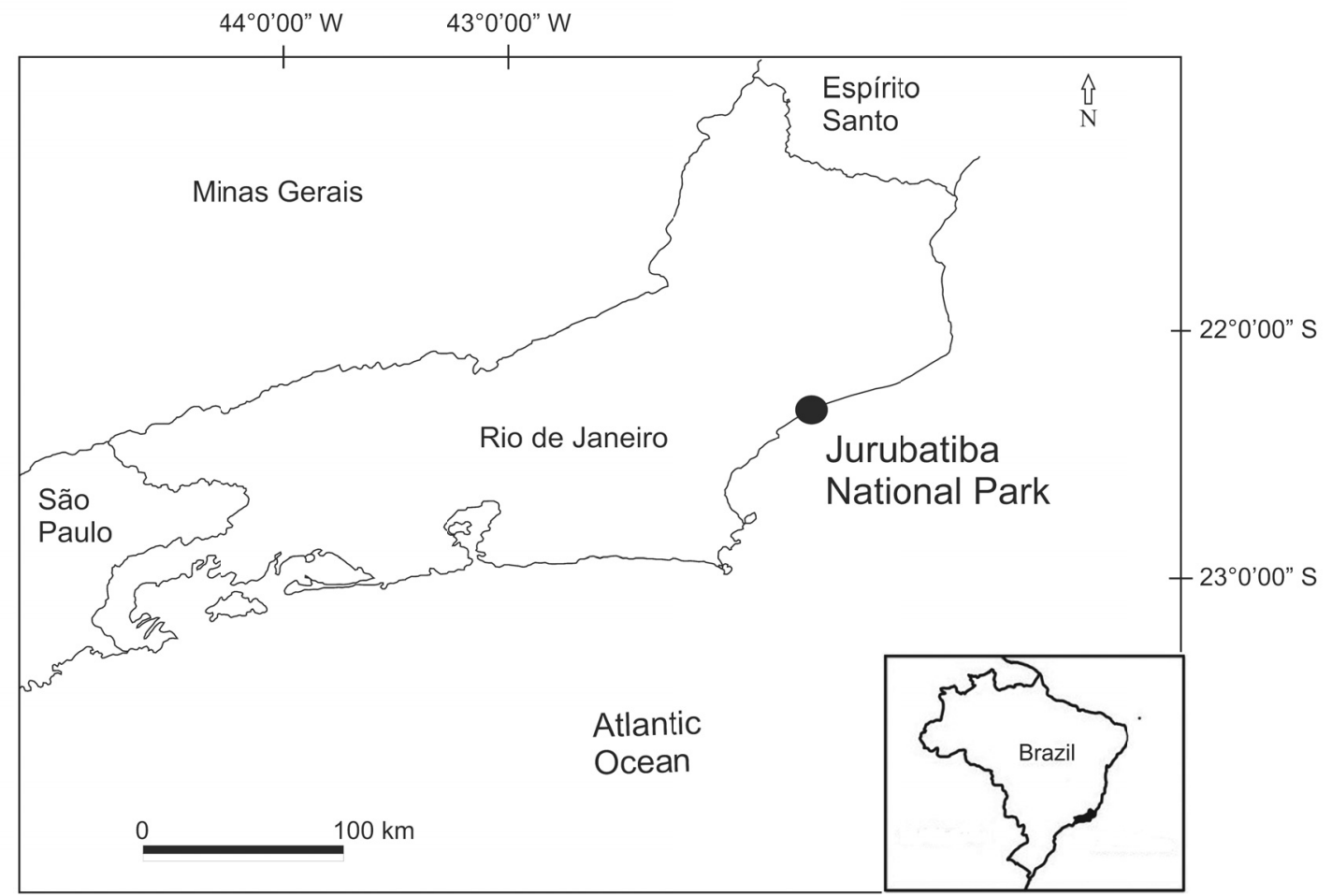

Figure 1 - Location of the Jurubatiba National Park, Rio de Janeiro state, southeastern Brazil.

Rummel and Roughgarden 1983), and most species are characteristic from the Atlantic Rainforest or from open habitats in general (Araújo 1984, 1994). Endemism is rare (Rodrigues 1990).

We conducted the study adjacent to the Cabiúnas lagoon $\left(22^{\circ} 16^{\prime} \mathrm{S}, 41^{\circ} 41^{\prime} \mathrm{W}\right)$, which corresponds to the sub-area that Henriques et al. (1986) designated as "open Clusia formation". There, the arbustive-arboreal vegetation is dominated by species of Clusiaceae, Myrtaceae, Erythroxylaceae and Burseraceae, with abundant bromeliads and cacti, and a high density of the dwarf sand palm ("guriri"), Alagoptera arenaria (Arecaceae) (Araújo et al. 1998).

\section{FIELD DATA COLLECTION AND ANALYZES}

We conducted field work in March 1999, although we also included data from lizards collected on earlier fieldwork in the area (i.e., April 1997, and January, September, October and December 1998). We restricted the study entirely to the months of wet season (October-April) in order to minimize possible effects of seasonality in our results. Data included both visual observation and specimen collection for diet analysis. We undertook visual observations during activity transects in areas different from those where we collected the lizards, but similar in phytophysiognomy. Our transects consisted of a precisely demarcated path (evidenced by a trail in the sand and bright orange tapes tied to the vegetation and spaced $10 \mathrm{~m}$ from one another). We made daily observations from 0600 to 1900 during three days (2-4 March 1999). A pair of researchers walked in transects during an average of 30 minutes each hour. All lizards seen were recorded and categorized according to species, microhabitat used at first sighted, and whether they were exposed to sun, shade or active under cloudy weather. Lizard taxonomy followed Pyron et al. (2013).

We classified microhabitat types in eight categories: (1) open sand, at the edge of bushes; 
(2) open sand, standing more than $20 \mathrm{~cm}$ away from the border of bushes; (3) on leaf-litter; (4) on tree trunks or branches; (5) inside shrubs; (6) bromeliad; (7) cactus; (8) dwarf palm. To nonfrequent species (i.e., Mabuya spp., Tupinambis merianae and Hemidactylus mabouia), we combined data on activity periods and microhabitat use gathered along transects (for Mabuya and Hemidactylus) or observed on other occasions (for T. merianae). Thus, data on microhabitat use were taken from all lizards collected plus those observed in activity transects during the hourly period of highest activity for each species (in order to avoid pseudoreplication of data).

We performed collections using air-pressure rifles, rubber bands, nooses, and glue traps. We placed the glue traps randomly on the leaf-litter near bromeliads and on bromeliad leaves, at the edge and inside bushes. All collected lizards were transferred to a plastic bag and euthanized with diethyl ether, method usually permitted at the time. For each specimen collected, we recorded the time of capture, type of microhabitat, and perch height (in $\mathrm{cm}$, for lizards perched above ground). We weighted the collected lizards in the field using Pesola $\subset$ dynamometers, individually identified and placed on ice.

In laboratory, we measured the lizards using digital calipers (snout-vent length, SVL, to the nearest $0.1 \mathrm{~mm}$ ) before preservation in $10 \%$ formalin. Later we examined stomachs and their contents under stereomicroscope. Animal prey was identified to Order (Hymenopteran insects were further subdivided in ants, non-ants) and plant matter was classified according to structure (i.e., leaf, flower or fruit). We measured length and width of each food item (excluding miscellaneous fragments) with digital calipers (to the nearest 0.1 $\mathrm{mm}$ ), and estimated their individual volumes with a modified version of the ovoid-spheroid formula (Dunham 1983): Prey size distributions were logtransformed (ln) to fit normal distribution. Using prey measures, we obtained the importance index
(Ix) (see Gadsden and Palacios-Orona 1997, Powell et al. 1990) for each prey category per lizard species. The index is calculated by the sum of the proportions for number, volume and frequency of each item, divided by three. We conducted this study under permission of Instituto Brasileiro do Meio Ambiente e Recursos Naturais Renováveis (IBAMA, authorization number 096/99-DIFAS).

We analyzed the niche overlap of four species, regarding three niche axes (time, space and trophic): Tropidurus torquatus (Wied, 1820), Cnemidophorus littoralis Rocha, Araújo, Vrcibradic \& Costa, 2000, Mabuya agilis (Raddi, 1823) and M. macrorhyncha Hoge, 1947. These species were selected due to their probable similar use of the habitat (T. torquatus and C. littoralis using the border of vegetation; and $M$. agilis and $M$. macrorhyncha using the inner portion of vegetation) (G.R. Winck, unpublished data). We tested the overlapping probability along each axis by null models (1,000 iterations or pseudocommunities) using the software EcoSim (Gotelli and Entsminger 2004), through estimations of the MacArthur and Levins' index modified by Pianka (1973) $(\phi)$. We used randomization algorithm numbers two and three (RA2 and RA3). RA2 relaxes the niche breadth and retains the zero states of resources (i.e., effectively not used), whereas the RA3 retains the resource use, while retaining the niche breadth of species (Gotelli and Graves 1996). Contrary to R2, R3 algorithm reshuffles the resources that were not used in nature by one species, assuming the hypothesis that these resources might be used in the absence of interspecific competition (Gotelli and Graves 1996). Luiselli (2008) suggested RA2 algorithm as the one that more often uncovers structure in trophic axis in lizard assemblages, whereas Winemiller and Pianka (1990) suggested RA3 as the most suitable for lizards in general. As our aim comprises different niche axis (not just the trophic one), we opted to use both algorithms. Also, most lizard species may be considered as diet generalist (Luiselli 2008), and that also seems to be 
the case in our assemblage. For temporal analysis, we used a matrix containing the relative frequency of species in each period sampled. For spatial analysis, we utilized the frequency of use of each microhabitat category. For trophic analysis, we used a matrix containing the importance index (Ix) of each prey category by species. Prey categories with an Ix lower than $5 \%$ in the diet of all lizards were excluded (following Gainsbury and Colli 2003).

In order to graphically display the niche relations among species based on the three niche axes, we calculated a unified index:; where " $T$ " is the number of niche axes and $\mathrm{NO}_{i, j, t}$ is the result of the estimated pairwise niche overlap (Geange et al. 2011). $\mathrm{NO}_{\mathrm{ij}}$ varies from zero (both distributions are dissimilar) to one (distributions coincide). We constructed a distance matrix for unified pairwise niche overlap using $\mathrm{d}_{\mathrm{ij}}=1-\mathrm{NO}_{\mathrm{ij}}$, and performed a non-metric multidimensional scaling (NMDS) for visualization (Geange et al. 2011).

\section{RESULTS}

We recorded seven lizard species in the restinga of Jurubatiba: Tropidurus torquatus (Tropiduridae), Cnemidophorus littoralis and Tupinambis merianae (Duméril \& Bibron, 1839) (Teiidae), Mabuya agilis and M. macrorhyncha (Scincidae), Hemidactylus mabouia (Moreau de Jonnès, 1818) (Gekkonidae), and Gymnodactylus darwini (Gray, 1845) (Phyllodactylidae). We are aware of the existence of Ameiva ameiva in the area, however, the species apparently has a low local abundance and we were not able to record it during the study. Tupinambis merianae was only observed, but not collected. Gymnodactylus darwini was collected only in glue traps set in the interior of shrubs and no individuals were observed during activity transects; thus no activity data was gathered for it. Only four specimens of $H$. mabouia were found during fieldwork. Therefore, we excluded these three species from niche overlap analyzes due to their low abundance.
For the temporal analysis, we used data on Tropidurus torquatus $(\mathrm{N}=698)$, C. littoralis $(\mathrm{N}=$ 57), M. macrorhyncha $(\mathrm{N}=11)$, and $M$. agilis $(\mathrm{N}=$ 11). Temporal niche overlap varied from $\phi=0.095$, for C. littoralis and M. agilis, to $\phi=0.688$ for $T$. torquatus and M. macrorhyncha (Table I). Mean observed index for both algorithms did not differ from the expected by chance (R2: $\phi_{\text {obs }}=0.42, \phi_{\exp }$ $=0.42, \mathrm{p}_{\mathrm{obs}} \leq \mathrm{p}_{\text {exp }}=0.49, \mathrm{p}_{\mathrm{obs}} \geq \mathrm{p}_{\text {exp }}=0.5 ; \mathrm{R} 3: \phi_{\text {obs }}=$ $0.42, \phi_{\exp }=0.39, \mathrm{p}_{\text {obs }} \leq \mathrm{p}_{\exp }=0.68, \mathrm{p}_{\text {obs }} \geq \mathrm{p}_{\exp }=0.32$; Figure $2 \mathrm{a}, \mathrm{b})$. Variance was low and similar for both algorithms: $\operatorname{var}(\mathrm{R} 2, \mathrm{R} 3)=0.004$.

\section{TABLE I}

Observed overlap indices for time of activity (temporal axis), microhabitat use (spatial axis), and diet (trophic axis) for four lizard species, in Jurubatiba National Park, Rio de Janeiro State, Brazil. TT = Tropidurus torquatus; $\mathrm{CL}=$ Cnemidophorus littoralis; $\mathrm{MA}=$ Mabuya agilis; $\mathrm{MM}$

$=M$. macrorhyncha. $\mathrm{NO}_{\mathrm{ij}}=$ estimated pairwise niche overlap considering all niche axes. Numbers in bold represent the highest and the lowest overlaps.

\begin{tabular}{|c|c|c|c|c|}
\hline \multicolumn{5}{|c|}{ Temporal axis } \\
\hline Species & TT & $\mathrm{CL}$ & MA & MM \\
\hline $\mathrm{TT}$ & 1 & 0.53 & 0.69 & 0.59 \\
\hline $\mathrm{CL}$ & & 1 & 0.38 & 0.09 \\
\hline MA & & & 1 & 0.23 \\
\hline MM & & & & 1 \\
\hline \multicolumn{5}{|c|}{ Spatial axis } \\
\hline Species & TT & $\mathrm{CL}$ & MA & $\mathrm{MM}$ \\
\hline TT & 1 & 0.99 & 0.14 & 0.45 \\
\hline $\mathrm{CL}$ & & 1 & 0.13 & 0.42 \\
\hline MA & & & 1 & 0.33 \\
\hline MM & & & & 1 \\
\hline \multicolumn{5}{|c|}{ Trophic axis } \\
\hline Species & TT & $\mathrm{CL}$ & MA & MM \\
\hline TT & 1 & 0.76 & 0.29 & 0.7 \\
\hline $\mathrm{CL}$ & & 1 & 0.18 & 0.93 \\
\hline MA & & & 1 & 0.39 \\
\hline MM & & & & 1 \\
\hline \multicolumn{5}{|c|}{ Mean niche overlap $\left(\mathrm{NO}_{\mathrm{ij}}\right)$} \\
\hline Species & TT & $\mathrm{CL}$ & MA & MM \\
\hline TT & 0 & 0.44 & 0.89 & 0.57 \\
\hline $\mathrm{CL}$ & & 0 & $>1$ & 0.69 \\
\hline MA & & & 0 & $>1$ \\
\hline MM & & & & 0 \\
\hline
\end{tabular}



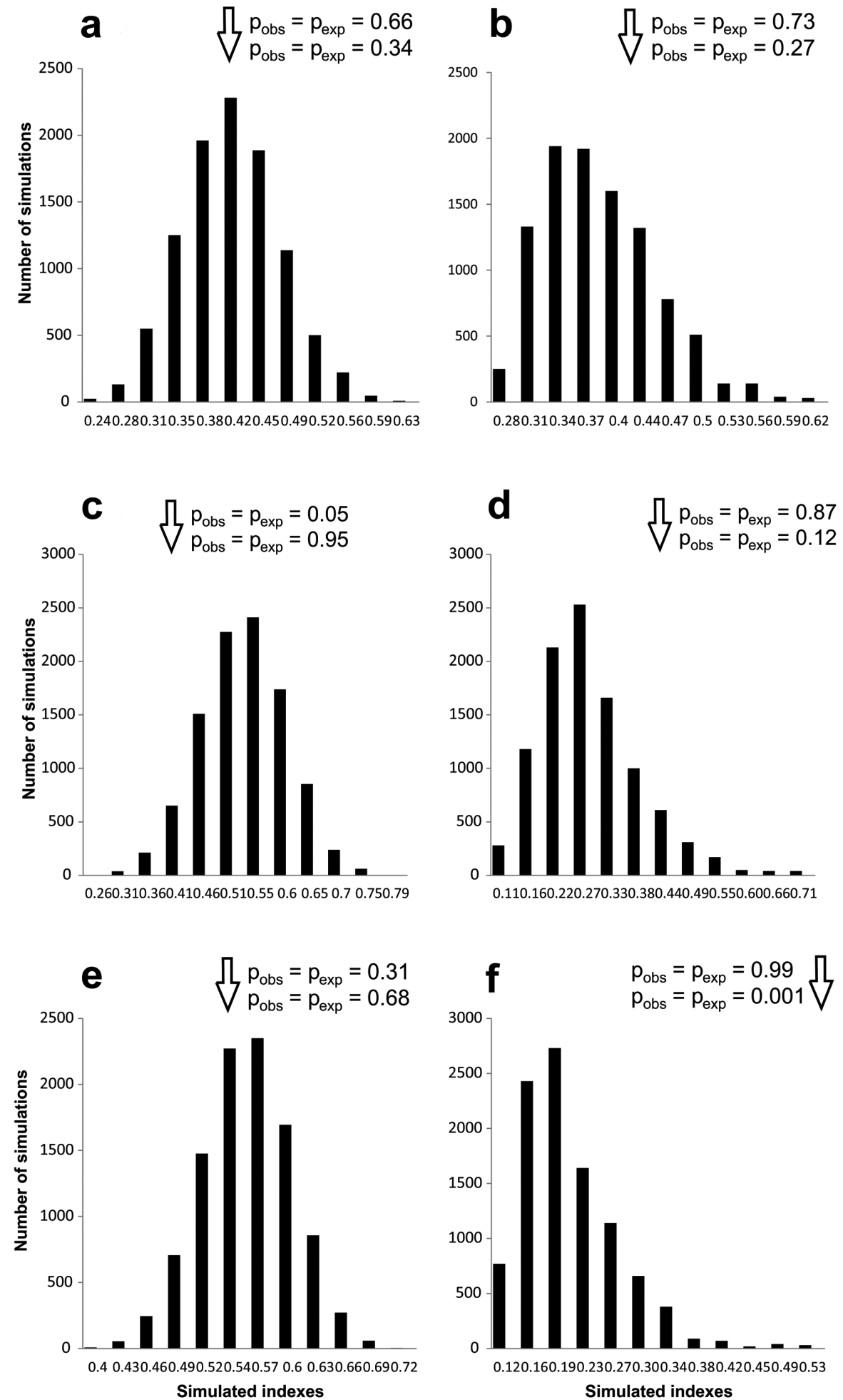

Figure 2 - Simulated pseudocommunities for niche overlap of a lizard community from a sand dune habitat, Rio de Janeiro state, Brazil. Arrows indicate the observed mean index for the analyzed species. $\mathrm{P}_{\text {obs }}$ = probability for observed mean; $\mathrm{P}_{\exp }=$ probability for expected mean. Left column comprises simulations performed through RA2 algorithm, whereas right column using RA3 algorithm. $\mathbf{a}, \mathbf{b}=$ temporal axis; $\mathbf{c}, \mathbf{d}=$ spatial axis; $\mathbf{e}, \mathbf{f}=$ trophic axis. 
In order to evaluate the overlap on spatial niche (microhabitat use), we used data on T. torquatus (N = 805), C. littoralis $(\mathrm{N}=92), M$. macrorhyncha $(\mathrm{N}=55)$, and $M$. agilis $(\mathrm{N}=11)$. Spatial niche overlap varied from $\phi=0.13$, for $C$. littoralis and M. macrorhyncha, to $\phi=0.99$ for $T$. torquatus and C. littoralis (Table I). Mean observed index was significantly lower from the expected by chance using R2 ( $\phi_{\text {obs }}=0.41, \phi_{\exp }=0.54, \mathrm{p}_{\text {obs }} \leq \mathrm{p}_{\exp }=0.05$, $\mathrm{p}_{\mathrm{obs}} \geq \mathrm{p}_{\text {exp }}=0.95$; Figure $2 \mathrm{c}$ ); whereas no significant difference was found when using R3 ( $\phi_{\exp }=0.29$, $\mathrm{p}_{\text {obs }} \leq \mathrm{p}_{\text {exp }}=0.87, \mathrm{p}_{\text {obs }} \geq \mathrm{p}_{\text {exp }}=0.12$; Figure $2 \mathrm{~d}$ ). The variance of simulated indices was low for both algorithms: $\operatorname{var}(\mathrm{R} 2)=0.006$ and $\operatorname{var}(\mathrm{R} 3)=0.01$.

For the trophic analysis, we used data from T. torquatus $(\mathrm{N}=58)$, C. littoralis $(\mathrm{N}=22), M$. macrorhyncha $(\mathrm{N}=40)$, and $M$. agilis $(\mathrm{N}=8)$ (Table I). The trophic niche overlap varied from $\phi=0.18$, for C. littoralis and M. macrorhyncha to $\phi=0.93$, for $C$. littoralis and $M$. agilis. The mean observed index using R2 did not differ from chance $\left(\phi_{\text {obs }}=0.54, \phi_{\text {exp }}=0.57, \mathrm{p}_{\text {obs }} \leq \mathrm{p}_{\exp }=0.31, \mathrm{p}_{\text {obs }} \geq \mathrm{p}_{\text {exp }}=\right.$ 0.68 ; Figure $2 \mathrm{e}$ ), whereas it was significantly higher than the expected using R3 $\left(\phi_{\exp }=0.21, \mathrm{p}_{\mathrm{obs}} \leq \mathrm{p}_{\exp }\right.$ $=0.99, \mathrm{p}_{\mathrm{obs}} \geq \mathrm{p}_{\exp }=0.004$; Figure $2 \mathrm{f}$ ). Variance of simulated indices was low for both algorithms: $\operatorname{var}(\mathrm{R} 2)=0.002$ and $\operatorname{var}(\mathrm{R} 3)=0.004$.

Jointly analyzing the three niche axes, there was no grouping among the lizard species (Fig. 3; final configuration stress $=0.001, \mathrm{RSQ}=0.28)$. Pairwise mean niche overlap $\left(\mathrm{NO}_{\mathrm{ij}}\right)$ shows the shortest distance between $T$. torquatus and $C$. littoralis, and the greater distances between the latter and M. agilis and between both Mabuya species (Table I).

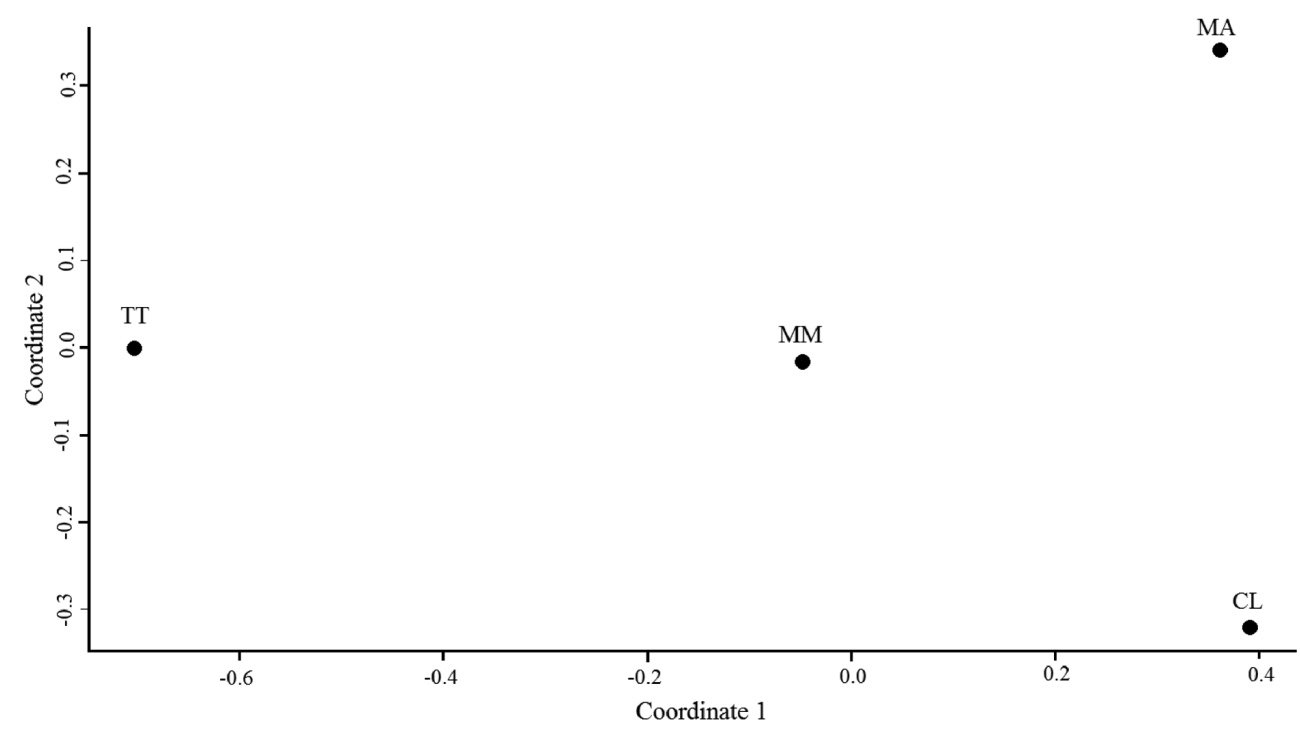

Figure 3 - Non-metric multidimensional scaling analysis showing statistical placing of each species, considering all three niche axis (temporal, space and trophic). TT = Tropidurus torquatus; $\mathrm{CL}=$ Cnemidophorus litorallis; $\mathrm{MA}=$ Mabuya agilis; $\mathrm{MM}=$ Mabuya macrorhyncha. Final configuration stress $=0.001 ;$ RSQ $=0.28$.

\section{DISCUSSION}

The species composition and structure of the lizard assemblage of Jurubatiba is quite similar as that of Barra de Maricá, except for the absence of the Liolaemid Liolaemus lutzae and low abundance of the teiid Ameiva ameiva (Hatano et al. 2001). Although the former was expected to be absent, since Jurubatiba lies outside its range (see Rocha 1986, Rocha et al. 2009), the low abundance of the latter was not expected. Ameiva ameiva is 
widely distributed in many habitats throughout South America (Vitt and Colli 1994), and usually is present in sand dune habitats along the Brazilian coast, where it is relatively abundant (Araújo 1994, Freire 1996, Rocha and Bergallo 1997). Rocha and Bergallo (1997), recorded A. ameiva in all of the nine sand dune sites they surveyed along $c a$. $1200 \mathrm{~km}$ of Brazilian coast, between latitudes $17^{\circ}$ and $23^{\circ} \mathrm{S}$. They noted, however, that population densities of this teiid varied considerably among areas depending of the structural habitat of each sand dune habitat. This may explain the comparatively very low density at the particular site (open Clusia formation) where this study was done. The phyllodactylid G. darwini was only sampled in glue traps. Its secretive habits and behavior make it difficult to detect in the field. This phyllodactylid occur in more shaded conditions in the innermost portions of shrubs (it was caught only in glue traps set at those places), combined with its cryptic coloration, low movement rate and reclusive habits. Thus, we believe that the low number of records of G. darwini in Jurubatiba may be an artifact of sub-sampling.

Regarding the niche overlap along the three axes, our data highlights the importance of the trophic axis in structuring the local lizard assemblage, under the assumption of niche breadth retaining (RA3 simulations). For the four species analyzed, it is probable that their coexistence is currently viable due to divergences in times of activity and use of space. The significant overlap in trophic axis may indicate some degree of resources partitioning and, therefore, the absence of competition (Pianka 1986, Gotelli and Graves 1996), or even a strong competition that did not lead to a divergence on the use of this particular type of resource until the present (Gotelli and Graves 1996). We believe that both scenarios may be possible as result of the relatively recent conformation of sand dune habitats (Pleistocene; see Martin et al. 1996, Cerqueira 2000), and due to the lack of data on when these environments were colonized by the lizard species that currently constitute the local community. Since Jurubatiba became isolated from other sand dune habitats (Rocha et al. 2007), and is currently highly impacted by human actions (Rocha et al. 2003, 2007), we believe that new colonization by other species (both lizards and their preys) is hardly possible. Therefore, an isolated community comprised mainly by active/mixed foragers may not be induced to diverge in trophic axis, if the resources remain stable. At the same time, lizards presenting a generalist and/or opportunistic diet seem to be the rule in communities worldwide (Luiselli 2008).

The knowledge on how lizard communities are structured is important especially for recent habitats where anthropogenic actions also stress the interaction among species, besides historical and ecological factors. The apparently constant result of trophic axis being the most important niche element was also found here. However, we believe that possible intraspecific variations on prey items could highlight hinder relations or even disregard the trophic axis influence found in more general studies concerning niche relations, such as the present.

\section{ACKNOWLEDGMENTS}

We are grateful to the Fundação Carlos Chagas Filho de Amparo à Pesquisa do Estado do Rio de Janeiro (FAPERJ) for current postdoctoral fellowship grant to GRW (processes E-26/101.237/2013 and E-26/101.267/2013) and support to CFDR through "Programa Cientistas do Nosso Estado" (processes E-26/102.765/2012 and E-26/202.920/2015). We are also grateful to Conselho Nacional de Desenvolvimento Científico e Tecnológico (CNPq), for financial support to CFDR (processes 304791/20105, 472287/2012-5 and 302974/2015-6) and to MVS (process 301401/2002-7).

\section{RESUMO}

As comunidades são estruturadas por uma interação de fatores históricos e ecológicos que influenciam o uso de 
diferentes recursos no tempo e no espaço. Coletamos dados sobre tempo de atividade, o uso de micro-habitat e dieta de uma assembleia de lagartos de um habitat de restinga na costa do Sudeste do Brasil (Restinga de Jurubatiba). Os dados foram analisados em relação à sobreposição de nicho entre as espécies ao longo de três eixos (temporais, espaciais e tróficos), utilizando modelos nulos. Encontramos uma sobreposição significativa no nicho trófico, enquanto que a sobreposição para os outros eixos não diferiu do esperado. Com base neste resultado, discutimos os fatores que atuam sobre a estruturação da comunidade local de lagartos.

Palavras-chave: modelos nulos, comunidades, restinga, lagartos, Brasil.

\section{REFERENCES}

ARAÚJO AFB. 1984. Padrões de divisão de recursos em uma comunidade de lagartos de restinga. In: Lacerda LD et al. (Orgs), Restingas: origem, estrutura e processos, Niterói: CEUFF, Rio de Janeiro, Brasil, p. 327-342.

ARAÚJO AFB. 1991. Structure of a white-sand dune lizard community of coastal Brazil. Rev Bras Biol 54(4): 857865.

ARAÚJO AFB. 1994. Comunidades de lagartos brasileiros. In: PUC/MG (Org), Herpetologia no Brasil, Belo Horizonte: Biodiversitas, Minas Gerais, Brasil, p. 58-68.

ARAÚJO DSD AND HENRIQUES RPB. 1984. Análise florística das restingas doEstado do Rio de Janeiro. In: Lacerda LD et al. (Orgs), Restingas: origem, estrutura e processos, Niterói: CEUFF, Rio de Janeiro, Brasil, p. 159-194.

ARAúJo DSD, SCARANO FR, DE SÁ CFC, KURTZ BC, ZALUAR HLT, MONTEZUMA RCM AND OLIVEIRA RC. 1998. Comunidades vegetais do Parque Nacional da Restinga de Jurubatiba. In: Esteves FA (Ed), Ecologia das Lagoas Costeiras do Parque Nacional de Jurubatiba e do Município de Macaé, RJ. Macaé: NUPEM, Rio de Janeiro, Brasil, p. 39-62.

BERGALLO HG AND ROCHA CFD. 1993. Activity patterns and body temperatures of two sympatric lizards with different foraging tactics. Amphibia-Reptilia 14: 312-315.

BERGALlo HG AND ROCHA CFD. 1994. Spatial and trophic niche differentiation in two sympatric lizards (Tropiduridus torquatus and Cnemidophorus ocellifer) with different foraging tatics. Austral Ecology 19: 72-75.

CARVAlho Alg, ARAúJo AFB AND Silva HR. 2007. Lagartos da Marambaia, um remanescente insular de Restinga e Floresta Atlântica no Estado do Rio de Janeiro, Brasil. Biota Neotr 7: 221-226.

CERQUEIRA R. 2000. Biogeografia das restingas. In: Esteves FA e Lacerda LD (Eds), Ecologia de Restingas e Lagoas
Costeiras, Rio de Janeiro: NUPEM/UFRJ, Rio de Janeiro, RJ, p. 65-75.

DUNHAM AE. 1983. Realized niche overlap, resource abundance, and intensity of interspecific competition. In: Huey RB, Pianka ER and Schoener TW (Eds), Lizard Ecology: Studies of a Model Organism. Harvard University Press, Cambridge, p. 261-280.

DUELLMAN WE. 1987. Lizards in an Amazonian rain forest community: resource utilization and abundance. Nat Geogr Res 3: 489-500.

FREIRE EMX. 1996. Estudo ecológico e zoogeográfico sobre a fauna de lagartos (Sauria) das dunas de Natal, Rio Grande do Norte e da restinga de Ponta de Campina, Cabedelo, Paraíba, Brasil. Rev Bras Zool 13: 903-921.

GADSDEN HE AND PALACIOS-ORONA LE. 1997. Seasonal Dietary Patterns of the Mexican fringe-toed Lizard (Uma paraphygas). J Herpet 31: 1-9.

GAINSBURY AM AND COLLI GR. 2003. Lizard assemblages from natural Cerrado enclaves in southwestern Amazonia: The role of stochastic extinctions and isolation. Biotropica 35: 503-519.

GEANGE SW, Pledger S, BuRnS KC AND SHIMA JS. 2011. A unified analysis of niche overlap incorporating data of different types. Methods Ecol Evol 175-184.

GOTELLi NJ AND ENTSMinger GL. 2004. EcoSim: Null models software for ecology. Version 7. Acquired Intelligence Inc. \& Kesey-Bear. Jericho, VT 05465. http:// garyentsminger.com/ ecosim/index.htm.

GOTELLI NJ AND GRAVES GR. 1996. Null models in Ecology. Washington: Smithsonian Institute, 368 p.

HATANO FH, VRCIBRADIC D, GALDINO CAB, CUNHABARROS M, ROCHA CFD AND VAN SLUYS M. 2001. Thermal ecology and activity patterns of the lizard community of the restinga of Jurubatiba, Macaé, RJ. Rev Bras Biol 61: 287-294.

HENRIQUES RPB, ARAÚJO DSD AND HAY JD. 1986. Descrição e classificação dos tipos de vegetação da restinga de Carapebus, Rio de Janeiro. Rev Bras Bot 9: 173-189.

LUISELLI L. 2008. Do lizard communities partition the trophic niche? A worldwide meta-analysis using null models. Oikos 117: 321-330.

MAGNUSSON WE, PAIVA LJ, ROCHA RM AND LIMA AP. 1985. The correlates of foraging mode in a community of Brazilian lizards. Herpetologica 41: 324-335.

MARTIN L, DOMINGUEZ JML AND BITTENCOURT ACSP. 2003. Fluctuating Holocene sea levels in Eastern and Southeastern Brazil: evidence from multiple fossil and geometric indicators. J Coastal Res 19: 101-124.

MARTIN L, SUGUIO K, DOMINGUEZ JML AND BITTENCOURT ACSP. 1996. Quaternary Sea-level History and Variation in Dynamics along the Central Brazilian Coast: Consequences on Coastal Plain Construction. An Acad Bras Cienc 68: 303-354. 
MARTINS M. 1991. The lizards of Balbina, Central Amazonia, Brazil: A qualitative analysis of resource utilization. Studies Neotrop Fauna Environ 26: 179-190.

Mesquita DO, COLli GR, FrançA FGR AND VitT LJ. 2006b. Ecology of a Cerrado Lizard Assemblage in the Jalapão Region of Brazil. Copeia 2006: 460-471.

MEsquitA DO, CostA GC AND COLLI GR. 2006a. Ecology of an Amazonian savanna lizard assemblage in Monte alegre, Pará state, Brazil. S Amer J Herpetol 1: 61-71.

PIANKA ER. 1973. The structure of lizard communities. Ann Rev Ecol Syst 4: 53-74.

PIANKA ER. 1986. Ecology and Natural History of Desert Lizards. New Jersey: Princeton University Press, 208 p.

POWELl R, PARMERLEE JS, RICE MA AND SMITH DD. 1990. Ecological observations on Hemidactylus brooki haitianus Meerwarth (Sauria: Gekkonidae) from Hispaniola. Caribb J Sci 26: 67-70.

PYRON R, BURBRINK FT AND WIENS JJ. 2013. A phylogeny and revised classification of Squamata, including 4161 species of lizards and snakes. BMC Evol Biol 13: 93.

RAND AS AND HUMPHREY SS. 1968. Interspecific competition in the tropical rain forest: ecological distribution among lizards at Belém, Pará. Proc U S Nat Mus 125: 1-17.

ROCHA CFD. 1998. Ontogenetic shift in the rate of plant consumption in a tropical lizard (Liolaemus lutzae). J Herpet 32: 274-279.

ROCHA CFD. 2008. Body size, female reproduction and sexual dimorphism in the lizard Ameiva ameiva (Teiidae) in a restinga of southeastern Brazil. Revta Bras Zool 25: 370-372.

ROCHA CFD AND BERGALLO HG. 1997. Intercommunity variation in the distribution of abundance of dominant lizard species in restinga habitats. Cien Cult 49: 269-274.

ROCHA CFD, BERGALLO HG, ALVES MAS AND VAN SLUYS M. 2003. A biodiversidade nos grandes remanescentes florestais do Estado do Rio de Janeiro e nas restingas dos corredores da Mata Atlântica. São Carlos: Rima, São Paulo, Brasil, 134 p.

Rocha CFD, Bergallo HG, VAn Sluys M, AlVES MAS AND JAMEL CE. 2007. The remnants of restinga habitats in the Brazilian Atlantic Forest of Rio de Janeiro state, Brazil: habitat loss and risk of disappearance. Braz J Biol 67: 263-273.

ROCHA CFD, SIQUEIRA CC AND ARIANI CV. 2009. The endemic and threatened lizard Liolaemus lutzae (Squamata: Liolaemidae): current geographic distribution and areas of occurrence with estimated densities. Rev Bras Zool 26: 454-460.

ROCHA CFD AND VRCIBRADIC D. 1996. Thermal ecology of two sympatric skinks (Mabuya macrorhyncha and Mabuya agilis) in a Brazilian restinga habitat. Aus Ecol 21: 110113.

ROCHA CFD AND VRCIBRADIC D. 1999. Reproductive traits of two sympatric skinks (Mabuya macrorhyncha and $M$. agilis) in a Brazilian restinga habitat. Herpet J 9: 43-53.
ROCHA PL AND RODRIGUES MT. 2005. Electivities and resource use by an assemblage of lizards endemic to the dunes of the São Francisco River, northeastern Brazil. Pap Avulsos Zool 45: 261-284.

RODRIGUES MT. 1990. Os lagartos da Floresta Atlântica brasileira: distribuição atual e pretérita e suas implicações para estudos futuros. Estrutura, manejo e função. In: II Simpósio Sobre Ecossistemas da Costa Sul e Sudeste Brasileira. São Paulo: Anais da Academia de Ciências do Estado de São Paulo, Brasil, p. 404-410.

RUMMEL JD AND ROUGHGARDEN J. 1983. Some differences between invasion-structured and coevolution-structured competitive communities: a preliminary theoretical analysis. Oikos 41: 477-486.

SALE PF. 1974. Overlap in resource use, and interspecific competition. Oecologia 17: 245-256.

SAZIMA I AND HADDAD CFB. 1992. Répteis da Serrado Japi: notas sobre história natural. In: Morellato LPC (Org), História Natural da Serra do Japi: Ecologia e Preservação de uma Área Florestal no Sudeste do Brasil, Campinas: Editora da Universidade Estadual de Campinas/Fundação de Apoio à Pesquisa do Estado de São Paulo, São Paulo, Brasil, p. 28-49.

SCHOENER TW. 1974. Resource Partitioning in Ecological Communities. Science 185: 27-39.

SIQUEIRA CC, KIEFER MC, VAN SLUYS M AND ROCHA CFD. 2013. Variation in the diet of the lizard Tropidurus torquatus along its coastal range in Brazil. Biota Neotrop 13: 93-101.

TEIXEIRA RL AND GIOvANELli M. 1999. Ecologia de Tropidurus torquatus (Sauria: Tropiduridae) da restinga de Guriri, São Mateus-ES. Rev Brasil Biol 59: 11-18.

TEIXEIRA-FILHO PF, ROCHA CFD AND RIBAS SC. 1995. Aspectos da ecologia termal e uso do habitat por Cnemidophorus ocellifer (Sauria: Teiidae) na restinga da Barra de Maricá, RJ. Oecol Bras 1: 155-165.

TOFT CA. 1985. Resource partitioning in amphibians and reptiles. Copeia 1985: 1-20.

VERRASTRO L AND BUJES CS. 1998. Ritmo de atividade de Liolaemus occipitalis Boulenger, 1885 (Sauria, Tropiduridae) na praia de Quintão, RS - Brasil. Rev Bras Zool 15: 907-914.

VERRASTRO L AND KRAUSE L. 1994. Analysis of growth in a population of Liolaemus occipitalis Boul. 1885, from the coastal sand-dunes of Tramandaí, RS, Brazil (Reptilia, Tropiduridae). Studies Neotrop Fauna Environ 29: 99-111.

VITT LJ. 1991. An introduction to the ecology of cerrado lizards. J Herpetol 25: 79-90.

VITT LJ. 1995. The ecology of tropical lizards in the Caatinga of northeast Brazil. Occ Pap Oklahoma Mus Nat Hist 1: $1-29$.

VITT LJ AND CARVALHO CM. 1995. Niche partitioning in a tropical wet season: lizards in Lavrado area of northern Brazil. Copeia 1995: 303-329. 
VITT LJ AND COLLI GR. 1994. The geographical ecology of a neotropical lizard: Ameiva ameiva (Teiidae) in Brazil. Can J Zool 72: 1986-2008.

VITT LJ AND PIANKA ER. 2005. Deep history impacts present day ecology and biodiversity. Proc Natl Acad Sci USA 102: 7877-7881.

VITT LJ AND ZANI PA. 1996. Ecology of the South American Lizard Norops chrysolepis (Polychrotidae). Copeia 1996: 56-68.

VITT LJ AND ZANI PA. 1998. Prey use among sympatric lizard species in lowland rain forest of Nicaragua. J Trop Ecol 14: 537-559.
VITT LJ, ZANI PA AND ESPÓSITO MC. 1999. Historical ecology of Amazonian lizards: implications for community ecology. Oikos 87: 286-294.

VRCIBRADIC D AND ROCHA CFD. 1996. Ecological differences in tropical sympatric skinks (Mabuya agilis and Mabuya macrorhyncha) in Southeastern Brazil. J Herpet 30: 60-67.

WINEMILlER KO AND PIANKA ER. 1990. Organization in Natural Assemblages of Desert Lizards and Tropical Fishes. Ecol Monogr 60: 27-55. 